\title{
PENANAMAN NILAI-NILAI NASIONALISME MELALUI PEMBELAJARAN SEJARAH DI SMA KEBANGSAAN YOGYAKARTA
}

\author{
Wira Fimansyah, Dyah Kumalasari \\ (Program Studi Ilmu Pengetahuan Sosial (IPS), Universitas Negeri Yogyakarta) \\ Email: wirafimansyah89@gmail.com,dyahkumala@gmail.com
}

\begin{abstract}
ABSTRAK
Penelitian ini bertujuan untuk mengetahui: (1) proses penanaman nlai-nilai nasionalisme melalui pembelajaran Sejarah, (2) kesulitan-kesulitan yang dialami oleh guru Sejarah, dan (3) upaya yang dilakukan oleh guru Sejarah untuk mengatasi kesulitan tersebut. Penelitian ini menggunakan metode kualitatif naturalistik, menggunakan snowball sampling. Data dikumpulkan melalui observasi, wawancara mendalam, dan dokumentasi. Teknik analisis data menggunakan model analisis interaktif Miles \& Huberman. Hasil penelitian menunjukkan: (1) Proses penanaman nilai-nilai nasionalisme melalui pembelajaran Sejarah di SMA Kebangsaan yakni melalui persiapan pembelajaran, pelaksanaan pembelajaran (menggunakan strategi yang bervariasi seperti merumuskan perasaan siswa melalui karikatur, cerpen, puisi, pantun, teka-teki silang dan memanfaatkan berbagai media yang disesuaikan dengan tujuan pembelajaran seperti film, gambar, artefak dan lain-lain), dan evaluasi. (2) Kesulitan-kesulitan yang dihadapi oleh guru Sejarah dalam proses penanaman nilai-nilai nasionalisme adalah latar belakang peserta didik yang berbeda-beda, kesulitan untuk mengontrol penggunaan internet, pemberitaan media massa (kurang contoh dari tokoh nasional), dan belum adanya laboratorium sejarah. (3) Upaya yang dilakukan oleh guru Sejarah dalam mengatasi kesulitan tersebut adalah dengan menjadikan dirinya sebagai teladan dan motivator bagi siswanya, mengadakan agenda wajib kunjungan ke tempat-tempat bersejarah, dan ikut serta dalam setiap acara peringatan hari-hari besar nasional.
\end{abstract}

\section{Kata Kunci: nasionalisme, pembelajaran sejarah}

\section{ABSTRACK}

This research aims to revead: (1) the inculcation of the nationalism values in the history lesson, (2) the difficulties that the teacher faces during the nationalism values implementation process, and (3) the efforts done by the history teacher as the attempt to overcome the difficulties those. The method used in this research was naturalistic qualitative method, used was the snowball sampling. The data collection was done through direct observation, in-depth interview, and documentation. The data analysis technique used was the interactive analysis model of Miles \& Huberman. The results of the research show that: (1)The inculcation process of the nationalism values in SMA Kebangsaan starting from the preparation of learning, implementations of learning (using strategy various such as expressions, feeling trough caricature, short story, poem, verse, crossword to discover the students depth nationalism, and using various media based on the purpose of learning historical science movies, pictures, artefac,etc) and evaluation.(2)The difficulties faced by the teacher in the nationalism-values inculcation process are caused by the various background of students, internet abuses, lack of news, and the insufficient school facilities. (3) The efforts done by the History teacher to overcome the difficulties are done by showing the teacher's role as the role and inspiring learning model, study tour to historical places, also participate in every national day event.

Keywords: nationalism, History learning 


\section{Pendahuluan}

Indonesia dari Sabang sampai Merauke berjajar pulau-pulau dengan semboyan Bhinneka Tunggal Ika, keragaman mozaik bangsa inilah yang membangun NKRI. Keberagaman bukan bencana tetapi berkah. (Nudji, 2015, p.405) berpendapat bahwa:

Indonesia is a country that comprises thousands of islands and it is inhabited by hundreds of races, ethnic groups and languages. Indonesian nation is built upon identical history and faith stood on diversity in equality. Nationalism is a view aims to develop sense of national belonging based on identical history and then join in become one to maintain loyalty to the nation and state.

Ini berarti Indonesia adalah negara yang terdiri dari ribuan pulau dan dihuni oleh ratusan ras, kelompok etnis dan bahasa. Bangsa Indonesia dibangun di atas sejarah keanekaragaman dalam kesetaraan. Nasionalisme adalah pandangan yang bertujuan untuk mengembangkan rasa nasional berdasarkan sejarah yang dimiliki dan kemudian bergabung menjaga kesetiaan kepada bangsa dan negara. (Soedirja dkk, 2003, pp.46-67) berpendapat bahwa pancasila pada hakikatnya adalah moral, moral bangsa Indonesia yang mengikat seluruh warga masyarakat baik sebagai perorangan atau sebagai kesatuan bangsa karena semuanya sudah diatur pada setiap butuir-butir pancasila sebangai lambang indonesia dengan bhinneka tunggal ika sebagai semboyan kita.

Negara dan bangsa akan tumbuh dengan sempurna apabila kondisi ketahanannya mulai dari pribadi, keluarga, lingkungan, wilayah, dan nasionalnya bagus. Watak atau karakter yang baik hanya akan didapat bila dibina, dibangun, ditempa dengan kebiasaan baik secara berkelanjutan, dan dijadikan tuntunan perubahan tanpa henti.
Watak seseorang tidak bisa semerta-merta berubah begitu saja tanpa diasah dari kecil. Jati diri seseorang akan membedakan secara hakiki dirinya dari orang lain, demikian pula jati diri suatu bangsa. Untuk menemukan kembali jati diri pribadi, maka ada tiga komponen utama yaitu system nilai (value sistem), sikap pandang (attitude), perilaku (behavior). Namun ketiga hal tersebut sudah mulai sulit ditemui pada diri anak bangsa saat ini pemuda lebih suka sesuatu yang bersifat instan dan tanpa menghiraukan norma-norma yang ada. Pada kenyataannya degradasi nasionalisme pemuda di tengah realitas bangsa saat ini jika kita gambarkan berada di titik rendah, semua kebijakan berkiblat pada neoliberalisme negara barat jadi patokan, sehingga kesejahteraan rakyat jauh dari cita- cita Founding Fathers (pendiri) bangsa ini, yang pernah di gaungkan seabad yang lalu.

Globalisasi sangat mengancam pemuda karena kondisi psikis pemuda terbilang masih labil sehingga mudah terpengaruh dari luar. Pemuda zaman sekarang sangat mudah terkena dampak westernisasi sehingga dengan sekejap bisa merubah nilai-nilai yang dipegang selama ini. Tetapi pemuda kurang sadar akan ancaman tersebut dan kurang menganggap pentingnya nasionalisme. Belakangan tawuran pelajar, pertikaian antar warga, pornografi, premanisme, prostitusi, pergaulan bebas ketika jauh dari pantauan orang tua, berpakaian seenak hati tanpa memikirkan adat istiadat dan parahnya tidak lagi menghormati orang tua.

Tidak hanya itu korupsi bukan hanya menjadi bagian dari budaya, tetapi juga telah menjadi bagian dari mata pencaharian untuk mendapatkan tambahan bagi biaya hidup dan gaya hidup yang semakin melambung tinggi, bahkan sekarang ini dalam praktiknya justru semakin tersistematis dan terlihat 
telaten. Yang disayangkan adalah nasib rakyat miskin yang semakin melarat sementara orang kaya akan semakin kaya dan menikmati berbagai macam fasilitasnya. Di dalam jurnal sekretariat Negara (Lubis, 2008, pp.120-121) juga menjelaskan bahwa:

Potret nasionalisme kemudian memudar, banyak yang beranggapan bahwa nasionalisme sekarang ini semakin merosot, di tengah isu globalisasi, demokratisasi, dan liberalisasi yang semakin menggila. Kasus ambalat dan lagu rasa sayang-sayange beberapa waktu lalu secara tiba-tiba menyeruakkan rasa nasionalisme kita dengan menyerukan slogan-slogan "Ganyang Malaysia"!. Seluruh masyarakat bersatu menghadapi ancaman dari luar. Namun anehnya, perasaan atau paham itu hanya muncul sesaat ketika peristiwa itu terjadi tidak ada dalam kehidupan kita sehari-hari. Pada akhirnya kita harus memutuskan rasa kebangsaan kita harus dibangkitkan kembali. Namun bukan nasionalisme dalam bentuk awalnya seabad yang lalu. Nasionalisme yang harus dibangkitkan kembali adalah nasionalisme yang diarahkan untuk mengatasi semua permasalahan di atas, bagaimana bisa bersikap jujur, adil, disiplin, berani melawan kesewenang-wenangngan, tidak korup, toleran, dan lain-lain. Bila tidak bisa, artinya kita tidak bisa lagi mempertahankan eksistensi bangsa dan negara dari kehancuran total.

Oleh sebab itu sejarah yang diajarkan di sekolah bisa memiliki peran strategis di dalam menanamkan nilai-nilai nasionalisme di dalam diri siswa sehingga memiliki kesadaran terhadap eksistensi bangsanya. Karena tanpa bingkai moral, pengajaran sejarah yang terlalu mengedepankan aspek kognitif atau fakta-fakta keras saja tidak akan banyak pengaruhnya dalam rangka memantapkan apa yang sering disebut sebagai jati diri kepribadian bangsa. Nasionalisme menurut (Kohn, 1965, p.9) seorang sejarahwan yang cukup terkenal dan paling banyak karya tulisnya mengenai nasionalisme, memberikan terminologi yang sampai saat ini masih digunakan secara relevan dalam pembelajaran di sekolah, yakni: "nasionalism is a state of mind in which the supreme loyalty of individual is felt to be due the nation state."

Nasionalisme merupakan suatu paham yang memandang bahwa kesetiaan tertinggi individu harus diserahkan kepada negara kebangsaan. Berdasarkan pendapat tersebut dapat ditarik kesimpulan bahwa nasionalisme sebagai suatu perasaan untuk bersatu karena adanya kepercayaan kepada bangsa dan latar belakang perasaan senasib, bersatu dalam keadaan yang beragam. Nasionalisme yang harus dimiliki oleh seluruh warga negara dapat ditanamkan kepada anak-anak baik di rumah maupun di sekolah.

Guru, orangtua dan masyarakat setidaknya dapat menanamkan motivasi kepada siswa agar memiliki semangat belajar yang tinggi hingga akhirnya dapat menggunakan ilmu mereka kelak untuk mencerdaskan generasi selanjutnya dibarengi dengan menanamkan nilai-nilai kejujuran, toleransi, disiplin, dan mementingkan kepentingan bersama daripada kepentingan pribadi, serta menghargai orang lain ini sudah merupakan indikator dari nasionalisme.

Lembaga pendidikan dalam hal ini sekolah juga mempunyai kewajiban untuk menanamkan nilai-nilai nasionalisme kepada siswa. Melalui pelajaran yang dapat menanamkan nilainilai nasionalisme dapat diambil makna dan diserap nilai-nilai nasionalisme yang disisipi oleh guru dan diwujudkan oleh peserta didik dalam kehidupan nyata 
hingga terbentuklah watak peserta didik yang mencintai bangsa dan Negaranya. Berikut merupakan tujuan dari pelaksanaan pendidikan sejarah dalam kurikulum 2006 seperti tercantum dalam Peraturan Menteri Pendidikan Nasional (Permendiknas) Nomor 22 Tahun 2006 adalah agar peserta didik memiliki kemampuan sebagai berikut:

Membangun kesadaran peserta didik tentang pentingnya waktu dan tempat yang merupakan sebuah proses dari masa lampau, masa kini, dan masa depan, melatih daya kritis peserta didik untuk memahami fakta sejarah secara benar dengan didasarkan pada pendekatan ilmiah dan metodologi keilmuan, menumbuhkan apresiasi dan penghargaan peserta didik terhadap peninggalan sejarah sebagai bukti peradaban bangsa Indonesia di masa lampau, menumbuhkan pemahaman peserta didik terhadap proses terbentuknya bangsa Indonesia melalui sejarah yang panjang dan masih berproses hingga masa kini dan masa yang akan datang, menumbuhkan kesadaran dalam diri peserta didik sebagai bagian dari bangsa Indonesia yang memiliki rasa bangga dan cinta tanah air yang dapat diimplementasikan dalam berbagai bidang kehidupan baik nasional maupun internasional.

Aman (2011:34-35) mengatakan bahwa materi sejarah merupakan bahan pendidikan yang mendasar bagi proses pembentukan dan penciptaan peradaban bangsa Indonesia di masa depan, menanamkan kesadaran persatuan dan persaudaraan serta solidaritas untuk menjadi perekat bangsa dalam menghadapi ancaman disintegrasi bangsa sarat dengan ajaran moral dan kearifan yang berguna dalam mengatasi krisis multidimensi yang dihadapi dalam kehidupan sehari-hari, dan berguna untuk menanamkan dan mengembangkan sikap bertanggung jawab dalam memelihara keseimbangan dan kelestarian lingkungan hidup.

Senada dengan penuturan di atas (Ahmad dkk, 2013. P.229) juga berpndapat bahwa:

History is related to the past. Throughout history, one can learn about the success of the nation. This allows the remembrance of past glories, instilling patriotism and subsequently honouring and preserving the independence and sovereignty of the country.

Sejarah berkaitan dengan masa lalu, melalui sejarah seseorang dapat belajar tentang keberhasilan bangsa. Dengan mengingat kejayaan masa lalu, bisa menanamkan patriotisme, kemudian menghormati dan melestarikan kemerdekaan dan kedaulatan Negara. Oleh sebab itulah pembelajaran sejarah di sekolah bisa lebih dioptimalkan agar dapat menanamkan nilai-nilai nasionalisme. Dan begitu juga dengan usaha dari pihak sekolah turut membantu dalam hal penanaman nilai-nilai nasionalisme kepada peserta didiknya supaya nilai-nilai tersebut bisa diwujudkan dalam kehidupan sehari-hari.

Berikut hasil observasi pada tanggal 23 Agustus s/d 10 November 2014 di SMA Kebangsaan Yogyakarta bahwa guru sejarah dari dulu sudah berusaha menanamkan nilai-nilai nasionalisme itu kepada peserta didik melalui proses pembelajaran di dalam kelas ataupun di luar kelas. Karena memang guru sejarah di SMA Kebangsaan ini berasal dari jurusan pendidikan sejarah yang sudah mempunyai tekad sejak awal bahwasanya misi dari mata pelajaran sejarah itu adalah untuk menanamkan nasionalisme kepada peserta didik.

Adapun kebijakan di SMA Kebangsaan yaitu upacara bendera tidak rutin diadakan setiap hari Senin, namun sebagai gantinya setiap pagi peserta didik 
diwajibkan setelah berdoa untuk menyanyikan lagu kebangsaan Indonesia Raya di dalam kelas masing-masing, dan bagi siapa pun yang terlambat diwajibkan untuk berhenti sembari mengheningkan cipta dan ikut bernyanyi ditempat mereka berhenti tersebut dan semua warga sekolah ini menaatinya, tata tertib dari pihak sekolah ini sudah berjalan lumayan lama dan bisa dipatuhi.

Ekstrakurikuler yang mendukung seperti pramuka, pleton inti, wayang, kerawitan dan gamelan serta selalu mempringati dan memeriahkan hari-hari besar bangsa dan memeriahkan acara tersebut dengan menggunakan budaya khas daerah Istimewa Yogyakarta. Hal ini sudah menjadi tradisi disini dan bertujuan untuk penanaman nilai-nilai nasionalisme pada peserta didik. SMA Negeri 11 Yogyakarta yang diresmikan pada tahun 1989 akhirnya juga disebut sebagai "SMA Kebangsaan" karena memiliki catatan sejarah yang panjang dan berbeda dari sekolah-sekolah negeri lainnya di Yogyakarta. Salah satunya dulu merupakan tempat dilakukannya kongres pertama Budi Utomo sebagai simbol Kebangkitan Nasional pada tahun 1908.

\section{Metode Penelitian}

Jenis Penelitian

Penelitian ini menggunakan metode kualitatif naturalistik. Metode penelitian kualitatif naturalistik merupakan metode yang digunakan untuk meneliti kondisi yang alamiah. Dalam hal ini peneliti menjadi partisipan penuh kemudian melakukan analisis deskriptif. (Prastowo, 2012, p.22) memaparkan bahwa kata kualitatif ditekankan pada makna dan proses, bukan pada pengukuran dan pengujian secara kaku (rigid) sebagaimana yang terjadi pada metode kuantitatif. Pada hakekatnya penelitian kualitatif merupakan satu kegiatan sistematis untuk menemukan teori dari kancah lapangan, bukan untuk menguji teori atau hipotesis.

Tempat dan Waktu Penelitian

Lokasi penelitian di SMAN 11 Yogyakarta, Lokasi penelitian ini dipilih karena melihat berbagai pertimbangan, salah satu alasan yang paling mendasari adalah latar belakang sekolah yang berbeda dengan sekolah negeri lainnya karena SMA Negeri 11 Yogyakarta ini mendapat sebutan sebagai "SMA Kebangsaan" karena latar belakang historinya. SMA Kebangsaan merupakan tempat dilaksanakannya kongres pertama Budi Utomo yang merupakan simbol kebangkitan nasional pada tahun 1908.

Penelitian ini dilaksanakan pada bulan November-April 2015. Informan dalam penelitian ini adalah Kepala Sekolah SMA Kebangsaan Yogyakarta, yakni: BY, Wakahumas yaitu EP, dan guru sejarah di SMA Kebangsaan Yogyakarta ini ada 2 orang yaitu SR dan SJ serta 6 orang siswa yang dijadikan sasaran penelitian, yang terlebih dahulu dipilih sesuai dengan kebutuhan dan kemantapan peneliti dalam memperoleh data.

Teknik dan Instrumen Pengumpulan Data Dalam metode penelitian kualitatif, peneliti bahkan sebagai instrument utama, dialah yang mengadakan sendiri pengamatan, atau wawancara, seringnya menggunakan buku catatan. Instrument lainnya adalah buku catatan, tape recorder (video/audio), kamera dan sebagainya, (Nasution, 1992, p.9). Teknik pengumpulan data pada penelitian ini dilakukan dengan beberapa cara, antara lain:

Observasi Langsung

Merupakan pengamatan dan pencatatan dengan sistematik terhadap fenomena-fenomena yang diteliti. 
Mengutamakan data langsung atau "first hand".

Wawancara Mendalam

Bertujuan untuk mengetahui apa yang terkandung dalam pikiran dan hati orang lain, yaitu hal-hal yang tidak kita dapatkan melalui observasi. Wawancara dalam penelitian ini menggunakan wawancara mendalam dengan menggunakan alat bantu yaitu pedoman wawancara. Dalam penelitian ini, peneliti menggunakan wawancara tidak terstruktur. Hal ini bertujuan agar mendapatkan lebih banyak informasi tentang penanaman nilai-nilai nasionalisme melalui pembelajaran sejarah di SMA kebangsaan Yogyakarta.

Dokumentasi

Hasil penelitian dari observasi atau wawancara akan lebih kredibel/dapat dipercaya apabila didukung oleh dokumen-dokumen yang mendukung. Bisa juga didukung oleh foto/gambar dan lain-lain.

Keabsahan Data

Pada penelitian ini peneliti menggunakan teknik triangulasi sumber. Triangulasi sumber berarti membandingkan dan mengecek kembali derajat kepercayaan suatu informasi yang diperoleh melalui waktu dan alat yang berbeda.

Teknik Analisis Data

Teknik analisis dalam penelitian ini dilakukan dengan menggunakan model analisis interaktif seperti yang diungkapkan oleh (Miles dan Huberman, 1994, p.12) yaitu proses analisis yang dilakukan bersamaan dengan proses pengumpulan data. Proses analisis ini melalui empat tahapan yaitu pengumpulan data, reduksi data, penyajian data dan penarikan kesimpulan.

\section{Hasil Penelitian dan Pembahasan \\ Sejarah singkat SMA Kebangsaan}

Gedung sekolah dibangun pada tahun 1897 di Yogyakarta dan digunakan sebagai gedung Kweekschool (sekolah guru zaman Belanda). Pada tanggal 3-5 Oktober 1908 dijadikan sebagai ajang Kongres Boedi Utomo yang pertama kali dan menempati ruang makan Kweekschool (yang sekarang dijadikan sebagai Aula) ruang serba guna di SMA Kebangsaan sekarang. Tahun 1946 sekolah dibuka kembali, karena sebelumnya sempat ditutup pada masa Revolusi Kemerdekaan RI untuk memenuhi kebutuhan tenaga guru yang berpendidikan 6 tahun pada bulan Nopember 1947, pemerintah membuka Sekolah Guru A (SGA) sehingga kompleks gedung menjadi SGA/SGB dipimpin oleh bapak Sikun Pribadi. Pada tahun 1989 Pemerintah mengalih fungsikan SPG menjadi SMA, SPG Negeri 1 menjadi SMA 11 Yogyakarta (Profil SMA 11 Yogyakarta: 2).

Berdasarkan SK Mendikbud RI No.0000/0/1989 yang menetapkan dibukanya SMA baru, maka terhitung mulai tanggal 9 september 1989 SMA Negeri 11 Yogyakarta berdiri. Akhirnya pada tanggal 20 Mei 2008 di ruang Aula Budi Utomo dijadikan tempat peringatan satu abad Budi Utomo oleh Bapak Menteri Pendidikan Nasional Bapak Prof. Dr. Bambang Sudibyo, MBA. Pada peringatan tersebut "SMA Negeri 11 Yogyakarta dicanangkan sebagai sekolah Pelopor Pendidikan Kebangsaan oleh Bapak Menteri Pendidikan" Sumber: (Profil SMAN 11 Yogyakarta: 2014).

Sejak beberapa tahun terakhir ini orientasi pengembangan SMA Negeri 11 Yogyakarta lebih mengarah ke sekolah modern yang unggul dalam kemampuan pelestarian budaya tata boga dan karawitan. Unggul dalam penguasaan Bahasa Inggris serta tekhnologi informasi dan komunikasi. Untuk mendukung arah pengembangan sekolah tersebut, maka dicanangkan suatu Visi, SMA Negeri 11 Yogyakarta sebagai berikut: 
"terwujudnya sekolah yang unggul intelektual, integritas, santun, berwawasan kebangsaan dan bercakrawala global".

Sementara itu Misi dari SMA 11

Negeri Yogyakarta adalah:

Menerapkan sistem layanan pendidikan yang bermutu berpedoman pada 8 Standar Nasional Pendidikan, mengembangkan kemampuan akademik bercakrawala global dengan penerapan dan pengembangan kurikulum lokal, nasional maupun internasional, mengembangkan potensi dan kreatifitas peserta didik secara optimal yang berakar pada nilai-nilai agama dan budaya nasional Indonesia sesuai dengan tuntutan globalisasi, menciptakan budaya sekolah yang sportif, kreatif, menyenangkan dan santun dengan penuh rasa kekeluargaan, membangun kerjasama dengan pihak luar sekolah sesuai dengan tuntutan globalisasi (Profil SMA 11 Yogyakarta: 4-6).

Usaha Sekolah untuk Menanamkan Nilai-Nilai Nasionalisme

BY selaku Kepala Sekolah SMA Kebangsaan menuturkan bahwa penanaman nilai-nilai nasionalisme tidak hanya bisa dilakukan melalui pembelajaran saja, tetapi juga bisa melalui peraturan-peraturan sekolah contohnya setiap pagi di SMA Kebangsaan diwajibkan mengumandangkan lagu kebangasaan Indonesia Raya sebelum pembelajran dimulai dan bagi siapapun yang terlambat harus berhenti ditempat dan ikut menyanyikan lagu tersebut. Dan bisa juga melalui kegiatan ekstrakurikuler seperti pramuka dan pleton inti hal ini dimaksudkan untuk melatih peserta didik agar disiplin, belajar bertanggung jawab, tertib dan jujur. Serta ada ekstrakurikuler yang mengarah kepada cinta produk dalam negeri yang menghidupkan kembali kebudayaan-kebudayaan khas daerah, contoh: kerawitan, gamelan, wayang, tata boga khas DIY. Tidak lupa pula budaya asli daerah dimasukkan ke dalam pembelajaran muatan lokal dengan tujuan agar melestarikan budaya daerah. Termasuk juga memberikan motivasi penuh kepada peserta didik untuk mengikuti berbagai perlombaan seni.

Pendapat lain juga dikemukakan oleh EP selaku kepala Humas di SMA Negeri 11 Yogyakarta yang mana pada tahun 1990 pernah menjadi Pembina TONTI (Pleton Inti) sekota Yogyakarta bahwa ciri khas dari SMA Kebangsaan itu adalah karena sejarahnya yang panjang sehingga menjadi kebanggaan tersendiri oleh warga sekolah, kebudayaan yang dijadikan muatan lokal dalam pembelajaran, sehingga untuk menanamkan nilai-nilai nasionalisme tersebut tidak begitu susah karena peserta didik sadar akan slogan yang dilekatkan pada sekolah tempat mereka menuntut ilmu yaitu SMA Kebangsaan.

Di sekolah Kebangsaan sering diadakan perlomboan guna memperingati hari-hari besar bangsa. Aula peninggalan Boedi Oetomo tersebut digunakan sebagai tempat untuk melaksanakan perlombaan-perlombaan tersebut. Contoh: pada tanggal 21-23 April 2015 bertepatan dengan Kamis Pahing di Aula ini semua warga sekolah berkumpul guna menyaksikan acara kartilas (Kartini SMA 11) dengan mengadakan lomba: sesorah, lomba Dimas dan Diajeng serta lomba wiruh jarik semua warga sekolah wajib mengenakan pakaian Khas Jawa lengkap dan menggunakan bahasa Jawa. Memang sudah jadi tradisi di SMA Kebangsaan bahwasanya setiap Kamis Pahing warga sekolah wajib mengenakan pakaian ngagrak ngayogyakarto guna melestarikan budaya asli daerah dan mengajarkan kepada peserta didik untuk bangga akan budaya khas daerah yang merupakan salah satu dari sekian banyak indikator dari nasionalisme. 
Proses Penanaman Nlai-Nilai

Nasionalisme pada Mata Pelajaran

Sejarah di SMA Kebangsaan

\section{a. Pesiapan pembelajaran}

Persiapan pembelajaran mulai dari penyusunan RPP yang awalnya didiskusikan melalui tim MGMP namun setelah itu boleh dirombak sesuai kebutuhan. Untuk rencana pelaksanaan pembelajaran (RPP), walaupun terkadang guru tidak langsung mengedit RPP tersebut tetapi dibaca sebelum masuk ke kelas dan selalu dilakukan perombakan sesuai dengan materi pelajaran dan kondisi kelas masing-masing dan itu semua sudah ada dalam kepala guru tersebut sebelum mengajar karena lain kelas lain iklimnya. Hal ini membuat guru sejarah harus selalu berfikir untuk mempersiapkan segala sesuatunya sebelum masuk ke kelas.

SR dalam pembuatan RPP selalu mempertimbangkan tentang penggunaan media, strategi atau metode apa yang tepat untuk menyisipkan tentang nilai-nilai nasionalisme kepada peserta didik dan selalu disesuaikan dengan materi pembelajaran tersebut. Disini guru sejarah SR dan SJ tersebut selalu berusaha meningkatkan pengetahuannya tentang pemberitaan yang lagi marak atau memikirkan apa kira-kira yang bisa dilakukan guna menarik minat peserta didik apalagi di jam-jam terakhir, agar proses penanaman nilai-nilai nasionalisme bisa berjalan dengan lancar (Wawancara tanggal 13 Februari 2015).

\section{b. Pelaksanaan}

Sanjaya, 2009 mengatakan bahwa strategi digunakan untuk memperoleh ketercapaian, kesuksesan, kemenangan atau keberhasilan dalam memncapai tujuan. Strategi pembelajaran merupakan rencana tindakan yang diambil guna ketercapainnya suatu tujuan pendidikan dengan memakai berbagai metode dan memanfaatkan segala macam media dan sumber daya/kekuatan dalam pembelajaran tersebut. Maka untuk menjalankan strategi itu tidak bisa lepas dari media pembelajaran yang sangat dibutuhkan dalam setiap mata pelajaran untuk memudahkan peserta didik dalam belajar dan supaya peserta didik semakin bersemangat dalam mempelajari materi tersebut, menghindari bosan dan jenuh dari peserta didik. Serta makna yang dimaksud lebih cepat sampai ke peserta didik.

Seperti yang diungkapkan oleh SR dan SJ bahwa Semua sarana dan prasarana yang ada pasti akan digunakan, seperti menggunakan LCD untuk menampilkan power point atau memutarkan film/video/lagu dan tak lupa selalu kalau ke kelas saya bawa speaker biar suara nya keras dan jelas, anak-anak jadi senang, dan biar kita tidak bosan dengan pemaparan fakta keras saja. Tetapi tergantung materinya juga, kalau tentang kolonialisme, nasionalisme, imperialism, tanam paksa, pendudukan jepang atau masa 1945 sampai reformasi dan proklamasi kemerdekaan nah ini tepat sekali dengan cara memutarkan video biar lebih menyentuh disaat anak mengikuti pembelajaran dan merasuk ke jiwa mereka.

Dari hasil observasi dan wawancara peneliti menemukakan bahwa setiap materi pelajaran sejarah bisa disisipkan nilai-nilai nasionalisme, tergantung bagaimana guru sejarah yang bersangkutan bisa memilih metode , media, strategi apa yang dipakai. Karena setiap tema bisa disesuaikan metode dan media pengajaran yang akan digunakan. 
Contoh materi proklamasi kemerdekaan Indonesia ini lebih cocok untuk menggunakan metode sosio drama agar historical mindednes (jiwa zamannya) lebih terasa oleh peserta didik. Pemilihan media dan strategi yang tepat dalam pembelajaran sangatlah penting untuk lebih meningkatkan minat belajar siswa terhadap pelajaran sejarah. Sehingga penyisipan nilai-nilai nasionalisme bisa berjalan dengan lancar.

Sebagai contoh salah satu ringkasan RPP yang disusun oleh SR adalah: Pada materi "Pejuangan Bersenjata dan Diplomasi". Dengan Standar Kompetensi yaitu merekonstruksi perjuangan bangsa Indonesia sejak masa Proklamasi hingga lahirnya Orde Baru. Dan Kompetensi Dasar yaitu merekonstruksi perkembangan masyarakat Indonesia sejak proklamasi hingga Demokrasi Terpimpin. Sedangkan indikatornya adalah mendiskripsikan, menganalisis kontak fisik rakyat Indonesia dengan Sekutu dan Belanda di berbagai daerah. Tujuan pembelajaran sebagai berikut Setelah mengikuti pembelajaran siswa dapat menganalisis kontak fisik rakyat Indonesia dengan Sekutu dan Belanda di berbagai daerah.

Dengan menggunakan metode pembelajaran ceramah Bervariasi, diskusi, pemutaran film, tanya jawab, penugasan. Strategi yang digunakan SR seperti meminta peserta didik untuk merumuskan semua perasaan yang mereka rasakan setelah mempelajari tema tersebut dan dituangkan kedalam bentuk bait puisi, pantun, karikatur, cerpen, atau teka-teki silang. Peserta didik boleh bebas memilih mau menuangkan dalam bentuk apa yang mereka suka, dari sinilah guru bisa menilai sejauh mana nilai-nilai nasionalisme yang dimiliki oleh masing-masing peserta didik.

Nilai karakter bangsa yang disisipkan pada materi tersebut adalah religius, jujur, toleransi, disiplin, kerja keras, mandiri, demokratis, rasa ingin tahu, semangat kebangsaan, cinta tanah air, menghargai prestasi, bersahabat, cinta damai, gemar membaca, peduli lingkungan, peduli sosial, tanggung jawab.

$\begin{array}{ccr}\text { Guru } & \text { sejarah } & \text { selalu } \\ \text { menyebutkan } & \text { ini } & \text { diawal }\end{array}$ pembelajaran karena ini termasuk dalam tujuan yang hendak dicapai oleh peserta didik. Dan setelah memutarkan film/memperlihatkan gambar tokoh-tokoh penting atau objek-objek sejarah yang bersangkutan dengan materi tersebut. Guru mengajak merenungkan kembali apa yang telah kita lakukan demi bangsa ini, apa yang harus kita lakukan demi menghormati semua jasa para pahlawan yang telah berkorban, bagaimana caranya mewujudkan nilai-nilai nasionalisme tersebut agar bisa diterapkan dalam kehidupan sehari-hari. Dengan demikian diharapkan agar penanaman nilai-nilai nasionalisme kepada peserta didik melalui pembelajaran sejarah bisa berhasil.

Dengan minat belajar yang tinggi akan mampu memberikan kesempatan yang lebih untuk mencari tahu makna dari pelajaran sejarah tersebut dan selanjutnya menjadi nilai-nilai yang dipegang teguh bagi kehidupannya. Usaha yang dilakukan oleh SR untuk menanamkan nilai-nilai nasionalisme kepada peserta didik adalah dengan gaya pengajaran yang santai, ada humor, namun tetap pada konteks materi pelajaran dan tidak lupa pula memanfaatkan semua tekhnologi 
yang ada, mulai dari internet, LCD yang disediakan oleh pihak sekolah untuk menampilkan video/film dan gambar , serta membawa speaker sendiri untuk pengeras suara ke dalam kelas agar peserta didik bisa mendengarkan dengan baik dan tersentuh. Berguna juga untuk memutarkan lagu agar anak tidak bosan saat mengerjakan tugas.

Berikut penuturan FM 17 th, yang menjabat sebagai ketua OSIS mengatakan bahwa Saya sebenarnya tidak suka belajar sejarah karena hanya fakta keras melulu atau berbelit-belit itu-itu saja, bosan, tetapi guru yang ini (SR) menyenangkan, selalu berusaha membawa speaker dan memutarkan video/film/gambargambar yang berbau sejarah yang sesuai topik pembelajaran jadi saya tidak bosan $\mathrm{lg}$ malah ikut merasa bangga terhadap para pahlawan, dari video tersebut kita bisa belajar tentang semangat, pantang menyerah, teliti dan menghargai jasa para pahlawan.

Hal tersebut didukung oleh teori dari (Quanchi \& Asofou So'o, 2003, p.8) yang memaparkan bahwa:

These skills enable your History students to understand their own past and the connections of the past to the present. Your students will then be better prepared to play a role and plan for the future. They will have a respect for the past, and know what they can do to protect and promote their own cultures and histories. They will become good citizens. They will be proud to tell the world who they are, where they come from and what they have achieved.

Memungkinkan siswa yang mempelajari sejarah untuk memahami masa lalu mereka sendiri dan koneksi dari masa lalu. Siswa Anda akan lebih siap untuk memainkan peran dan rencana untuk masa depan. Mereka akan menghormati masa lalu, dan tahu apa yang bisa mereka lakukan untuk melindungi dan mempromosikan budaya dan sejarah mereka sendiri. Mereka akan menjadi warga negara yang baik. Mereka akan bangga untuk memberitahu dunia siapa mereka, dari mana mereka berasal dan apa saja yang telah mereka raih.

Seperti yang diungkapkan oleh SR dan SJ segala cara akan dilaksanakan agar tujuan pembelajaran tercapai sehingga Semua sarana dan prasarana yang ada pasti akan digunakan, seperti menggunakan LCD untuk menampilkan power point atau memutarkan film/video/lagu dan tak lupa selalu kalau ke kelas saya bawa speaker biar suaranya keras, jelas, anak-anak jadi senang, dan biar kita tidak bosan dengan pemaparan fakta keras saja.

Tetapi tergantung materinya juga, kalau tentang kolonialisme, nasionalisme, imperialism, tanam paksa, pendudukan jepang atau masa 1945 sampai reformasi ini tepat sekali dengan cara memutarkan video biar lebih menyentuh disaat anak mengikuti pembelajaran dan merasuk ke jiwa mereka. Selain itu penggunaan media foto, maupun artefak juga dapat membantu siswa untuk lebih mencintai sejarah dan akan lebih tertarik untuk mencari informasi yang lebih mendetail tentang sejarah tersebut.

Bahkan tidak cukup hanya di dalam kelas di luar kelas juga penanaman nilai-nilai nasionalisme tetap bisa dilaksanakan oleh guru sejarah seperti penuturan SJ bahwa: "Agenda wajib IPS study tour ke tempat-tempat bersejarah, jadi anakanak bisa melihat langsung peninggalan sejarah, dan saya berikan tugas kelompok untuk laporan dari 
hasil pengamatan tersebut, jalan-jalan tapi dapat ilmu“. Hal serupa juga dipaparkan oleh (Soewarso, 2000, pp.108-124) bahwa beberapa macam media yang terpenting dalam pebelajaran sejarah adalah Peninggalan Sejarah (Objek), Model atau replika, gambar, bagan waktu, peta, dan beberapa media modern yang sangat berguna seperti Berita radio dan televisi, Slide dan filmstrip, video dan ruang sejarah.

Hal tersebut didukung pula oleh teori dari (Kochhar, 2008, pp.212-214) bahwa alat-alat bantu pembelajaran menawarkan berbagai jenis pengalaman, mulai dari yang langsung dan penuh tujuan ke pengalaman terencana, dari pengalaman yang didramatisasi ke demonstrasi, karya wisata, gambar bergerak, gambar visual, dan symbolsimbol visual dan verbal. Semua itu memberikan selingan yang menyenangkan bagi peserta didik. Peserta didik akan memperhatikan dengan lebih baik di kelas jika menulis, mendengar, melihat, dan membaca seraya berfikir. Saranasarana itu menambah kesenangan dan minat.

Berikut penuturan salah seorang siswa bernama WK (16 th) bahwa pada dasarnya saya tidak tertarik dengan pelajaran sejarah, tapi dengan metode seperti ini saya semakin suka dengan sejarah, karena dengan mempelajari sejarah kita jadi nambah ilmu, jadi tahu, tidak semenamena lagi terhadap jasa para pahlawan, sehingga perjuangan seperti di film itu membuat saya semakin sadar dan harus membalasnya dengan rajin belajar dan mencintai tanah air ini. Oleh sebab itulah SR selalu berusaha melakukan yang terbaik demi terlaksananya penanaman nilainilai nasionalisme. Berikut penururanya:
Untuk penugasan agar peserta didik mudah memaknai tema saya sering menyuruh siswa merumuskan perasaannya terhadap tema yang baru saja dipelajari, misalkan tentang pendudukan Jepang di Indonesia, dituangkan melalui bait puisi, pantun, karikatur, cerpen, selain itu pengisian LKS masih sering juga digunakan. Disamping anak senang dan bersemangat melakukannya dan guru bisa mengetahui kreatifitas masingmasing anak.

Ini merupakan masukan yang bagus untuk sesama guru sejarah. Dan dinilai efektif untuk mengetahui sejauh mana perhatian peserta didik tentang nasionalisme tersebut. Senada dengan itu seorang siswa bernama SK memaparkan bahwa:

Dengan tugas yang sedemikian rupa kami jadi bersemangat dalam belajar sejarah sekaligus bisa memaknai nilai-nilai nasionalisme yang terkandung didalam materi, contoh ketika pendudukan Jepang bagi yang bisa melukis mereka bisa tuangkan perasaannya lewat karikatur, atau lewat puisi, atau lewat cerpen itu semua bisa membangkitkan rasa solidaritas dalam diri kami, sehingga belajar sambil berkreasi dan menyelami masa lampau". (01 April 2015).

Ide lain yang sering digunakan oleh guru sejarah di SMA Kebangsaan Yogyakarta ini adalah pada akhir BAB pembelajaran sejarah beliau sering menugaskan peserta didik untuk membuat teka-teki silang mendatar dan menurun secara berkelompok karena materinya cukup banyak, dan siswa mengaku sangat senang belajar sambil bermain. SR 
mengatakan "belajar sejarah itu jangan menjemukan, tapi buatlah menyenangkan, biar siswa-siswinya tidak mengantuk, bisa juga selagi mengerjakan LKS diputarkan lagulagu kebangsaan atau lagu-lagu pop, dangdut, dan lain-lain yang sekarang lagi terkenal dan sering didengar, dengan demikian anak tidak akan mengantuk saat mengerjakan tugas”.

Evaluasi

Berdasarkan wawancara dengan guru sejarah SMA Kebangsaan Yogyakarta evaluasi yang dilakukan guru sejarah dalam hal penanaman nilai-nilai nasionalisme adalah mencakup aspek kognitif, afektif dan psikomotorik. Berupa tes tertulis, pengamatan dan hasil-hasil tugas. Di perkuat dengan pernyataan SR sebagai berikut evaluasi yang disiapkan untuk hasil yang maksimal dalam menanamkan nilai-nilai nasionalisme adalah memperhatikan kriteria ketuntasan minimal (KKM=76), membuat soal-soal pilihan ganda, uraian, benar-salah, tugas rumah untuk aspek kognitif, untuk aspek keterampilan dalam membuat kreasi, entah itu berupa puisi, pantun, karikatur, cerpen, atau teka-teki silang, ini untuk aspek psikomotorik sangatlah berguna. Untuk sikap, bagi peserta didik yang melakukan kesalahan langsung ditegur dan diberikan sanksi, agar jera. Dan untuk ini guru berusaha mengenali masing-masing peserta didik melalui pengamatan.

Kesulitan-Kesulitan yang dihadapi oleh Guru Sejarah dalam Proses Penanaman Nilai-Nilai Nasionalisme.

Pertama, latar belakang peserta didik yang berbeda-beda. Sifat anak yang egois karena berasal dari keluarga mampu dan sudah terbiasa mendapatkan sesuatu yang diinginkan dengan mudah mendorong anak menjadi individualisme, tidak perduli antar sesama karena mereka punya semuanya, akibatnya susah dalam berbaur dengan masayarakat yang dipentingkan hanya dirinya sendiri. Oleh sebab itulah penanaman nilainilai nasionalisme ini harus dari kecil, dari keluarga (orang tua), dan lingkungan tempat peserta didik tinggal, ini sangat mempengaruhi. Jika hanya diharapkan dari guru di sekolah saja maka agak susah.

Kedua, adalah kesulitan dalam mengawasi/mengontrol penggunaan internet. Berikut penuturan SR:

Perkembangan IPTEK yang canggih ini turut berdampak pada pola pikir peserta didik dan terkena pengaruh globalisasi yang cendrung lebih ke negatif daripada positifnya jikalau tidak terkontrol. Dengan adanya internet setiap orang bisa mengakses apapun dan dimanapun hanya dengan bermodalkan HP. Sementara itu orang tua dan guru tidak akan bisa mengontrol 24 jam penuh, mengawasi apa saja yang sedang diakses oleh anak mereka (SR/13-02-15).

Ketiga, adalah pemberitaan di media massa (kurangnya contoh dari tokoh nasional). Kebanyakan hanya mempertontonkan hal-hal negatif yang tidak selayaknya dipertontonkan untuk khalayak ramai yang merupakan contoh tidak baik bagi perkembanganpeserta didik.

Keempat, adalah belum adanya laboratorium sejarah di SMA Kebangsaan. Senada dengan itu (Soewarso, 2000, p.124) juga mengemukakan bahwa penyediaan ruang sejarah ini terutama untuk mendinamisir 
pembelajaran sejarah menjadi pembelajaran yang hidup, reflektif dalam jiwa peserta didik dan membangkitkan perspektif bagi masa kini dan masa yang akan datang, maka yang pertama yang harus diingat adalah pemberian tekanan yang lebih besar pada kreativitas siswa sendiri dalam mengatur, mengisi serta memanfaatkan ruang sejarah tersebut.

Upaya yang dilakukan oleh Guru Sejarah untuk Mengatasi KesulitanKesulitan yang Muncul dalam Menanamkan Nilai-Nilai Nasionalisme di SMA Kebangsaan

Upaya yang dilakukan oleh guru sejarah dalam mengatasi kesulitankesulitan tersebut adalah dengan menjadikan dirinya sebagai teladan bagi peserta didiknya, mengadakan agenda wajib kunjungan ke tempat-tempat bersejarah, lalu dengan berusaha menjadi motivator bagi peserta didiknya, dan selalu ikut serta dalam setiap acara peringatan hari-hari besar nasional. SMA Kebangsaan menjadikan study tour sebagai agenda wajib untuk peserta didik. Hal ini bermaksud agar peserta didik bisa melihat langsung dan mendengarkan penjelasan langsung tentang tempat sejarah yang dikunjungi.

Menambah pengalaman dan menggali rasa ingin tahu dari setiap peserta didik, setelah kunjungan selesai nanti di kelas akan dilanjutkan dengan diskusi seputar tempat sejarah tersebut. Dengan demikian peserta didik akan lebih mencintai sejarah bangsanya dan perlahan-lahan mulai mengaktualisasi kan nilai-nilai nasionalisme tersebut dalam kehidupan sehari-hari.

Pelaksanaan guru sebagai teladan dilakukan secara teoretis maupun praktik secara langsung. Contoh: guru masuk ke kelas selalu tepat waktu, tegas, dan menyampaikan pembelajaran secara jujur. Guru sejarah selalu berusaha untuk tidak korupsi waktu dalam mengajar, datang tepat waktu, jujur dalam menyampaikan materi, mau meluruskan hal-hal yang kontroversial. Hal tersebut didukung dengan teori yang dikemukakan oleh (Zamroni, 2001,p.76) bahwasanya untuk mengembangkan nasionalisme dikalangan peserta didik guru dituntut:

Untuk: (1) memanfaatkan "hidden curriculum" dan kegiatan kokurikuler seefektif mungkin, (2) berani mendiskusikan isu-isu kemasyarakatan yang kontroversial, mengembangkan materi pelajaran dari realitas sekitar tidak hanya dari apa yang ada di buku. (4) berani mengundang praktisi ke dalam kelas, (5) menekankan pada anak didik "berpikir secara global, dan bertindak bersifat local", (6) menekankan makna efisiensi tidak semata-mata bermakna ekonomis, tetapi meliputi pula keharmonisan dengan lingkungan, solidaritas dan kebaikan untuk kesemuanya, (7) mampu berperan sebagai model bagi peserta didik.

Guru menjadi motivator dengan memberi semangat dan motivasi kepada peserta didiknya. SR selalu mengingatkan bahwa tidak ada orang bodoh di dunia ini yang ada hanya orang pemalas, jadi tidak perlu minder jika tidak sehebat teman-temannya yang lain. Disela-sela pembelajaran SR sering memutarkan video-video motivasi untuk peserta didik seperti video Kick Andy Show yang temanya bisa membangkitkan semangat peserta didik, contoh: yang pernah diperlihatkan kepada peserta didik "mengejar mimpi" seorang anak dari wilayah timur Indonesia-Papua bisa menjadi ahli matematika karena keuletan dan semangatnya. 
Guru sejarah SMA Kebangsaan juga selalu berusaha melakukan yang terbaik, menggali lagi ide-ide cemerlang lainnya untuk menanamkan nilai-nilai nasionalisme kepada peserta didik. Pertama peserta didik dibuat menyukai pelajaran sejarah terlebih dahulu, dan jika sudah begitu maka untuk menanamkan nilai-nilai nasionalisme tidak akan terlalu sulit. Seperti yang diungkapkan oleh OY, dan DS peserta didik kelas XI ini sepakat mengatakan bahwasanya:

Setelah mempelajari sejarah dengan guru yang bersahaja, dan memiliki banyak strategi dalam mengajar, kami jadi sadar kalau memang sejarah itu penting, persis seperti bung Karno bilang jangan sesekali melupakan sejarah, apalagi disuguhkan dengan video/film/gambar/yang diringi musik yang gagah berani, kami jadi sadar, hanya dengan belajar sungguhsungguh kita bisa membalas jasa para pahlawan yang telah tiada (wawancara pada tanggal 13 Februari 2015).

\section{Penutup}

Simpulan

Berdasarkan hasil penelitian yang dilakukan di SMA Kebangsaan Yogyakarta pada bulan November s/d April 2015, maka dapat ditarik beberapa kesimpulan:

Pertama, proses penanaman nilainilai nasionalisme melalui pembelajaran sejarah di SMA Kebangsaan sudah dilaksanakan yakni melalui melalui persiapan pembelajaran (pemantapan RPP), pelaksanaan pembelajaran (menggunakan strategi yang bervariasi seperti merumuskan perasaan peserta didik melalui karikatur, cerpen, puisi, pantun, atau teka-teki silang guna menggali sejauh mana nilai-nilai nasionalisme yang dimiliki oleh masing- masing peserta didik dan memanfaatkan berbagai media yang disesuaikan dengan tujuan pembelajaran seperti film, gambar, artefak dan lain-lain), dan evaluasi (berupa tes tertulis, pengamatan, dan hasil-hasil tugas). Untuk menanamkan nilai-nilai nasionalisme kepada peserta didik, guru sejarah SMA Kebangsaan Yogyakarta pertama kali berusaha untuk mendekatkan diri kepada peserta didiknya, lalu menghapus mindset bahwasanya pelajaran sejarah itu membosankan, tidak menyenangkan, pelajaran yang tidak popular yang selama ini sering didengar oleh peserta didik, setelah itu menumbuhkan minat kepada peserta didik akan mata pelajaran sejarah dan memvariasikan berbagai metode dan strategi dalam mengajar guna menyisipkan nilai-nilai nasionalisme ke dalam materi pelajaran sehingga mudah untuk dimaknai oleh peserta didik.

Kedua, kesulitan-kesulitan yang dihadapi oleh guru sejarah dalam proses penanaman nilai-nilai nasionalisme diantaranya latar belakang peserta didik yang berbeda-beda, kesulitan untuk mengawasi atau mengontrol penggunaan internet, pemberitaan media massa (kurang contoh dari tokoh nasional), dan belum adanya laboratorium sejarah di SMA Kebangsaan.

Ketiga, upaya guru sejarah untuk mengatasi kesulitan-kesulitan yang muncul di SMA Kebangsaan dalam proses menanamkan nilai-nilai nasionalisme tersebut adalah dengan menjadikan dirinya sebagai teladan bagi peserta didiknya, mengadakan agenda wajib kunjungan ke tempat-tempat bersejarah, lalu dengan berusaha menjadi motivator bagi peserta didiknya, dan selalu ikut serta dalam setiap acara peringatan hari-hari besar nasional.

\section{Saran}

Berdasarkan hasil riset terhadap kon-disi real yang ada di SMA 
Kebangsaan Yogyakarta dalam proses penanaman nilai-nilai nasionalisme, maka peneliti memberikan beberapa saran sebagai berikut:

Pertama, semua guru SMA Kebangsaan agar selalu mempertahankan tradisi sekolah yang selama ini sudah dilaksanakan, seperti mengajak peserta didik agar selalu melestarikan budaya asli daerah, kedisiplinan dan ketertiban warga sekolah. Dan selalu berusaha menggali ide-ide cemerlang yang lebih effektif dan meningkatkan inovasi dan kreasi dalam penggunaan metode, strategi, dan media pembelajaran supaya pananaman nilai-nilai nasionalisme bisa selalu terealisasi.

Kedua, diharapkan pihak sekolah bisa melengkapi laboratorium sejarah sehingga memudahkan guru sejarah untuk menanamkan nilai-nilai nasionalisme. Ketiga, generasi muda khususnya untuk peserta didik SMA Kebangsaan agar tetap menjadi anak bangsa yang membanggakan, walaupun kelak sudah tamat dari SMA Kebangsaan ini. Dan tidak mudah terkena dampak globalisasi dan westernisasi.

Keempat, orang tua supaya bekerja sama dengan pihak sekolah untuk menanamkan nilai-nilai nasionalisme kepada anak-anaknya, semenjak dari kecil dan berawal dari hal-hal kecil juga. Kelima, masyarakat awam dan pemberitaan media massa semoga lebih mendidik lagi kedepannya. Supaya tidak lagi menanamkan stigma negatif kepada generasi muda, bahwa pelajaran sejarah itu tidak penting, karena kuno dan tidak ada gunanya dimasa depan atau pemberitaan yang tidak berbobot. Karena stigma-stigma negatif semacam itulah yang membuat generasi muda tidak peduli akan sejarah bangsanya dan pengorbanan para pahlawan sehingga terlena oleh arus globalisasi yang semakin deras saat ini.

Keenam, bagi peneliti. Penelitian ini dapat dijadikan sebagai pembelajaran, dan suatu saat bisa diterapkan di kampung halaman tempat peneliti berasal. Sekaligus menjadi referensi penelitian berikutnya pada tempat dan waktu yang berbeda.

\section{Ucapan Terima Kasih}

Dalam kesempatan ini, penulis mengucapkan terima kasih kepada berbagai pihak yang telah membantu terlaksananya penelitian ini. Tak lupa, penulis juga menyampaikan ucapan terima kasih kepada dewan redaksi Jurnal Istoria terbitan Pendidikan Sejarah, Fakultas Ilmu Sosial, Universitas Negeri Yogyakarta atas kesempatan yang diberikan sehingga tulisan ini dapat dipublikasikan pada edisi Maret 2015.

\section{Daftar Pustaka}

Aman. 2011. Model evaluasi pembelajaran sejarah.

Yogyakarta. Ombak.

Kochhar, S.K. 2008. "Teaching of history". (Terjemahan Purwanta \& Yovita Hardiwati). Pembelajaran sejarah. Jakarta: P.T Grasindo.

Kohn, Hans (1965). Nationalism: its meaning and history. New York: D Van Nostrand Company.

Lubis, N.H. 2008. Potret nasionalisme bangsa indonesia masa lalu dan masa kini. Jurnal Kementrian Sekretariat Negara RI No. 08.

Miles, M. B. \& Huberman, A. M. (1994). Qualitative data analysis.

London: Sage Publications, Inc.

Nasution. 2002. Metode penelitian naturalistik kualitatif. Bandung: Tarsito.

Nudji. 2015. An effort to enhance sense of nationalism for students of senior high school through 
pendidikan pancasila and kewarganegaraan $\quad(P P K N)$. Academic Research International Vol. 6 (1) January 2015.

Peraturan Menteri Pendidikan Nasional Republik Indonesia Nomor 22 Tahun 2006 Tentang Standar Isi Untuk Satuan Pendidikan Dasar dan Menengah. 2006. Jakarta.

Prastowo, Andi. 2012. Metode penelitian kualitatif dalam perspektif rancangan penelitian. Yogyakarta. Ar-Ruzz Media.

Quanchi, M \& Asofou So'o. 2003. Teaching history a guide for teachers teaching history for the first time. Australia: National University of Samoa.

Sanjaya, W. 2009. Strategi pembelajaran beroientasi standar proses pendidikan. Jakarta: Kencana

Soedirja, S, Prawiro, R, et al. 2003. Membangun kembali karakter bangsa. Jakarta: Elex Media Komputindo.

Soewarso. 2000. Cara-cara penyampaian pendidikan sejarah untuk membangkitkan minat peserta didik mempelajari sejarah bangsanya. Departemen Pendidikan Nasional. Jakarta.

Zamroni. 2001. Pendidikan untuk demokrasi. Yogyakarta: Bigraf Publishing. 